Design and investigation of molybdenum modified platinum surfaces for modeling of CO tolerant electrocatalysts

Topics in Catalysis Volume 61 (2018) 1385-1395.

Bakos I, Borbáth I, Vass Á, Pászti Z, Tompos A

https://doi.org/10.1007/s11244-018-1035-X

Corresponding author: Irina Borbáth

Article history:

Accepted: 25 May 2018; published online: 24 August 2018 


\title{
Design and investigation of molybdenum modified platinum surfaces for modeling of CO tolerant electrocatalysts
}

\author{
I. Bakos ${ }^{1}$, I. Borbáth ${ }^{1 *}$, Á. Vass ${ }^{1}$, Z. Pászti ${ }^{1}$, A. Tompos ${ }^{1}$ \\ ${ }^{1}$ Institute of Materials and Environmental Chemistry, Research Centre for Natural Sciences, \\ Hungarian Academy of Sciences, H-1117 Budapest, Magyar tudósok körútja 2, Hungary
}

\begin{abstract}
Mo overlayers were prepared on smooth polycrystalline platinum and platinized platinum electrode surfaces by in situ electrochemical deposition of molybdenum oxide at potential below $500 \mathrm{mV}$ for modeling Mo-Pt electrocatalysts. Correlations were found between the applied potential and the amount of deposited Mo, which never exceeded a monolayer, thus Pt-Mo bonds stabilize the deposited Mo oxide. Electrochemical measurements suggested that Mo deposited from a Mo(VI) solution was reduced to the 4+ oxidation state. In line with the ex situ XPS findings a certain part (20-25\%) of the initial Mo layer remained irreversibly adsorbed on the $\mathrm{Pt} / \mathrm{Pt}$ electrode even after oxidation into the 6+ state at high potentials; this fractional monolayer cannot be dissolved even by prolonged cyclic polarization up to $1000 \mathrm{mV}$.

It has been demonstrated that the irreversibly bound Mo partial monolayer is enough to change significantly the $\mathrm{CO}$ poisoning properties of the Pt surface. On this Mo:Pt (1:4) surface CO oxidation is initiated at extremely low potentials (ca. $100 \mathrm{mV}$ ). Moreover, only $\mathrm{Pt}$ modified by $\mathrm{Mo}(\mathrm{IV})$ species is active in low-potential $\mathrm{CO}$ oxidation reaction as after oxidizing the irreversibly adsorbed Mo to the 6+ state, $\mathrm{CO}$ oxidation is no longer observable. Nevertheless, the catalyst can be reactivated by reduction of molybdenum into the 4+ oxidation state. However, this reduction requires clean, $\mathrm{CO}$-free $\mathrm{Pt}$ surface. If $\mathrm{Pt}$ is largely covered by $\mathrm{CO}$, reduction of $\mathrm{Mo}(\mathrm{VI})$ into $\mathrm{Mo}(\mathrm{IV})$ does not occur and thus the low potential CO oxidation remains hindered.
\end{abstract}

Keywords: In situ electrochemical deposition, Molybdenum oxide, Pt electrodes, Optimized surface composition, Anode electrocatalysts, CO-tolerance

\footnotetext{
* Corresponding author, Tel.: +36 1382 6916, email: borbath.irina@ttk.mta.hu, address: H-1519 Budapest, P.O.Box 286, Hungary (Irina Borbáth)
} 


\section{Introduction}

Polymer Electrolyte Membrane Fuel Cells (PEMFCs), due to their low operation pressure and temperature, form a very attractive class of fuel cells particularly suited for low and medium power mobile applications. Key components of a PEM fuel cell are the electrocatalysts on which the anode (hydrogen oxidation) and cathode (oxygen reduction) reactions take place. The optimal electrocatalyst should be highly active both in hydrogen oxidation and oxygen reduction, possess good long term stability and have adequate electrical conductivity at an affordable price. Experience shows that still platinum supported on active carbon is the most suitable choice both at the cathode and the anode. However, the sensitivity of $\mathrm{Pt}$ for poisoning by contaminants in the fuel (especially $\mathrm{CO}$ ), together with the pronounced corrosion of the active carbon support under fast load change conditions [1,2] can only be compensated by extremely high Pt loadings, which keeps the price of the PEMFCs high.

Recent investigations suggest that some of the limitations of the $\mathrm{Pt} / \mathrm{C}$ system can be overcome by applying a second oxophilic metal. In general, reactive hydroxyl species form more easily on the oxophilic additive than on Pt, which not only enhances the hydrogen oxidation reaction rate [3-5] but is also beneficial in the much slower oxygen reduction process [6,7], and facilitates easy oxidation of the CO contaminant as well via the so-called bifunctional mechanism [8,9], supposed that atomic closeness between the oxophilic sites and $\mathrm{Pt}$ is ensured. In these systems the additive may be present as an alloying component in the carbon supported Pt nanoparticles; examples involve Pt-Sn [10,11], Pt-Mo [12-17] or Pt-Ru $[18,19]$, which is also commercially available as the state-of-art CO-tolerant electrocatalyst recommended for PEM fuel cells. Moreover, due to the beneficial co-catalytic effect of Mo in $\mathrm{CO}$ and ethanol oxidation numerous studies were focused on the preparation of a wellcharacterized Pt-Mo bulk alloy electrodes [20-23].

Apart from alloying, the required atomic closeness of the oxophilic component and $\mathrm{Pt}$ may also be ensured if the former is applied as support or as a modifier of the active carbon support. Numerous works investigated the properties of such systems in which Pt is supported either by molybdenum- [24] or tungsten-oxides [25] or by active carbon doped with these oxides [26-30]. According to these studies, molybdenum- or tungsten oxides offer several advantages when they are used as components of the support for Pt electrocatalysts [31-35]. Apart from enhanced tolerance against poisoning by the bifunctional effect, the adsorption properties of the Pt particles can be tuned by changing their electronic properties by the ligand effect. In addition, hydrogen spillover from Pt towards the oxide may enhance the catalytic activity and electrooxidation of small organic molecules may be promoted. Moreover, 
stabilization of the highly dispersed state of the noble metal nanoparticles can be achieved by strong metal-support interaction, which prevents their agglomeration. Finally, relative stability is expected from these oxides across the anticipated potential/pH window.

The vast majority of heterogeneous catalytic reactions occur at high temperature and elevated pressure. As a result, elucidation of structure-activity-stability relationships under in operando conditions is still challenging. Electrocatalysts for PEMFC applications form a notable exception, as a significant amount of information about their behavior can be obtained by simple electrochemical measurements under conditions closely resembling those found in fuel cell electrodes. Thus it is not surprising that extensive studies have been done on the development of $\mathrm{Pt}-\mathrm{MoO}_{\mathrm{x}}$ model electrodes, in which atomic closeness of Pt atoms and Mo ions is ensured. These catalysts can be prepared by means of versatile techniques. Most synthetic routes use either co-deposition of the Pt and Mo precursors on glassy carbon electrodes [36-38] or Mo deposition on platinum single crystals $[39,40]$ or platinum $[41,42]$ or platinized platinum electrodes [43,44]. The resulting systems contain molybdenum in different oxidation states depending on the synthetic procedure.

Molybdenum oxides include five Magnéli phases with compositions between $\mathrm{MoO}_{2}$ and $\mathrm{MoO}_{3}$ [45]. $\mathrm{MoO}_{2}$ has a rutile-type structure and unusually high electronic conductivity [46], while $\mathrm{MoO}_{3}$, which is more stable under oxidative conditions [47], has an orthorhombic structure and is non-conducting. However, it can be electrochemically reduced to a nonstoichiometric and electroconductive hydrogen molybdenum bronze. The formation of $\mathrm{H}_{\mathrm{x}} \mathrm{MoO}_{3}$ endows $\mathrm{MoO}_{3}$ with high electronic and proton conductivity [48]. Usually, molybdenum oxides do not exist in a single phase but in mixed-valence oxides $\left(\mathrm{MoO}_{x}\right)$ [49]. The lattice defect structure and self-diffusivity of oxygen are the determining factors of the electrochemical properties concomitant with the changing valence state of molybdenum [50]. In agreement with the bifunctional mechanism, the co-catalytic activity is supposed to be due to a rapid and easy change of the oxidation state of molybdenum.

Although reducible oxides of oxophilic metals are indeed valuable co-catalysts or supports for PEMFC electrocatalysts, their dissolution under the working conditions of the cell is always a concern, as dissolved metal cations can absorb in the polymer membrane, resulting in the loss of its proton conducting property [51]. To overcome this problem, a composite support was proposed, in which the oxophilic metal co-catalyst is incorporated into a $\mathrm{TiO}_{2}$ matrix which provides long term stability, while the good electrical conductivity and high surface area of the system is ensured by an active carbon backbone. The preparation and 
the thorough characterization of Pt electrocatalysts deposited onto $\mathrm{Ti}_{0.7} \mathbf{M}_{0.3} \mathrm{O}_{2}-\mathrm{C}(\mathrm{M}=\mathrm{W}, \mathrm{Mo})$ composites was presented in our recent studies [52-54].

Using $\mathrm{Pt} / \mathrm{Ti}_{(1-\mathrm{x})} \mathrm{Mo}_{\mathrm{x}} \mathrm{O}_{2}-\mathrm{C}(\mathrm{x}=0.2-0.4)$ catalytic systems it has been demonstrated $[53,54]$ that the oxidation of $\mathrm{CO}$ takes place at exceptionally low potentials (the onset potential $\mathrm{E}_{\mathrm{CO} \text {,onset }} \leq 100 \mathrm{mV}$ ) compared to the $\mathrm{Pt} / \mathrm{C}$ and $\mathrm{PtRu} / \mathrm{C}$ catalysts. Additionally, a characteristic feature of the cyclic voltammograms of the $\mathrm{Pt} / \mathrm{Ti}_{(1-\mathrm{x})} \mathrm{Mo}_{\mathrm{x}} \mathrm{O}_{2}-\mathrm{C}$ catalysts is the appearance of a molybdenum redox peak pair between 380 and $530 \mathrm{mV}$. The mixed oxide component increased the $\mathrm{CO}$ tolerance under simulated $\mathrm{CO}$ poisoning conditions by providing adsorbed hydroxyl species $\left(\mathrm{OH}_{\mathrm{ads}}\right)$ for $\mathrm{CO}$ oxidation at very low electrode potentials $[54,55]$. After the weakly bound CO is oxidized, surface sites released in this way can adsorb some hydrogen [25,54]. Thus, in the presence of CO impurities oxophilic dopant-containing composites improved the catalytic activity in the hydrogen oxidation reaction (HOR) with respect to conventional $\mathrm{Pt} / \mathrm{C}$ catalysts $[53,54]$.

The results of the mentioned investigations suggested a possible correlation between the molybdenum redox phenomenon and the $\mathrm{CO}$ tolerant behaviour of the Mo-containing electrocatalysts. To further elucidate this point, model experiments were designed in which the electrochemical properties of Pt-Mo catalytic surfaces prepared by in situ electrochemical deposition of Mo on smooth polycrystalline platinum and platinized platinum electrodes were explored. Using electrochemical methods the amount of irreversibly deposited Mo and the change of the oxidation state of molybdenum during polarisation were assessed. The influence of the molybdenum oxidation state on the $\mathrm{CO}$ tolerance and stability of the Mo-Pt/Pt electrode was also investigated. The results reported here are supposed to give insight into the processes determining the activity and stability of the Mo-containing Pt-based electrocatalysts and may also give hints about the optimum surface composition and Pt/Mo ratio in real catalysts.

\section{Experimental}

\subsection{Electrochemical experiments}

Mo-Pt bimetallic model electrocatalyst surfaces were prepared by electrodeposition of Mo-species onto platinum. Ammonium heptamolybdate tetrahydrate $\left(\left(\mathrm{NH}_{4}\right)_{6} \mathrm{Mo}_{7} \mathrm{O}_{24} \times 4 \mathrm{H}_{2} \mathrm{O}\right.$, Merck, 99\%) was used as Mo precursor compound. Two types of Pt electrode were used: smooth polycrystalline $\mathrm{Pt}$ and platinized platinum with a relatively large real surface area (roughness factor - R between 200 and 250).

A special three-compartment electrochemical cell was used, in which the solution of the main compartment could be replaced with deoxygenated electrolyte with the exclusion of 
air. Hydrogen electrode was used as reference and a Pt sheet as counter electrode. All potentials are given on RHE scale. All electrochemical measurements were carried out at ambient temperature. The electrolyte was $0.5 \mathrm{M} \mathrm{H}_{2} \mathrm{SO}_{4}$ (Merck, P.A.).

Solutions were prepared from Millipore MilliQ water and p.a. reagents. 5.5 N Ar gas was used for deoxygenation the solutions. Real surface area of Pt was estimated from the amount of charge used for oxidation of the adsorbed hydrogen.

\subsection{Physical characterization}

To estimate the amount of adsorbed Mo on smooth Pt electrodes, ex situ X-ray photoelectron spectroscopy (XPS) measurements were carried out using an EA125 electron spectrometer manufactured by OMICRON Nanotechnology GmbH (Germany). The electrodes were transferred to the electron spectrometer under water to minimize air exposure and avoid excessive oxidation. The photoelectrons were excited by nonmonochromatized $\mathrm{MgK} \alpha(1253.6 \mathrm{eV})$ radiation. Spectra were recorded in the Constant Analyser Energy mode of the energy analyser with $30 \mathrm{eV}$ pass energy resulting in a spectral resolution around $1 \mathrm{eV}$. Binding energies were referenced to the Fermi edge of the Pt foil. Data were processed using the CasaXPS software package [56] and the XPS MultiQuant software package [57].

\section{Results and Discussion}

\subsection{Preparation of Mo modified Pt surfaces}

Fig. 1 compares the cyclic voltammograms (CVs) of a smooth polycrystalline platinum electrode recorded using different cathodic potential limits in $0.5 \mathrm{M} \mathrm{H}_{2} \mathrm{SO}_{4}$ solution containing $5 \times 10^{-4} \mathrm{M} \mathrm{Mo}(\mathrm{VI})$ precursor compound $\left(\left(\mathrm{NH}_{4}\right)_{6} \mathrm{Mo}_{7} \mathrm{O}_{24} \times 4 \mathrm{H}_{2} \mathrm{O}\right) . \mathrm{CV}$ of the $\mathrm{Pt}$ electrode recorded in pure $\mathrm{H}_{2} \mathrm{SO}_{4}$ solution is also depicted for comparison.

In the Mo-free solution, a typical $\mathrm{CV}$ of $\mathrm{Pt}$ with the classical features of the underpotentially deposited hydrogen adsorption/desorption (i, i') between $50 \mathrm{mV}$ and $350 \mathrm{mV}$ along with platinum oxide formation (iii) and its reduction region can be identified. Comparing the voltammograms of platinum electrode in the solutions with and without heptamolybdates it is obvious that significant changes take place on the surface in the molybdenum containing solution. The massive cathodic current below $550 \mathrm{mV}$ indicates some reduction process and since the hydrogen adsorption and desorption (i, i') peaks of the platinum disappeared it can be concluded that the product of this reduction totally covered the platinum surface. 
As shown in Fig. 1 upon using different potential limits during the cyclic polarization the quantity of the Mo-species electrodeposited on the surface of Pt electrode can be varied. Upon shift of the potential limit from $400 \mathrm{mV}$ to $100 \mathrm{mV}$ the amount of adsorbed Mo-species increases. Accordingly, as can be seen from Fig. 1, the highest peak of the oxidation of adsorbed Mo-species (ii) was detected at the potential limit of $100 \mathrm{mV}$. It also can be seen from Fig. 1, that deposition of Mo-species starts at more positive potentials comparing to the beginning of the $\mathrm{H}$-adsorption on platinum.

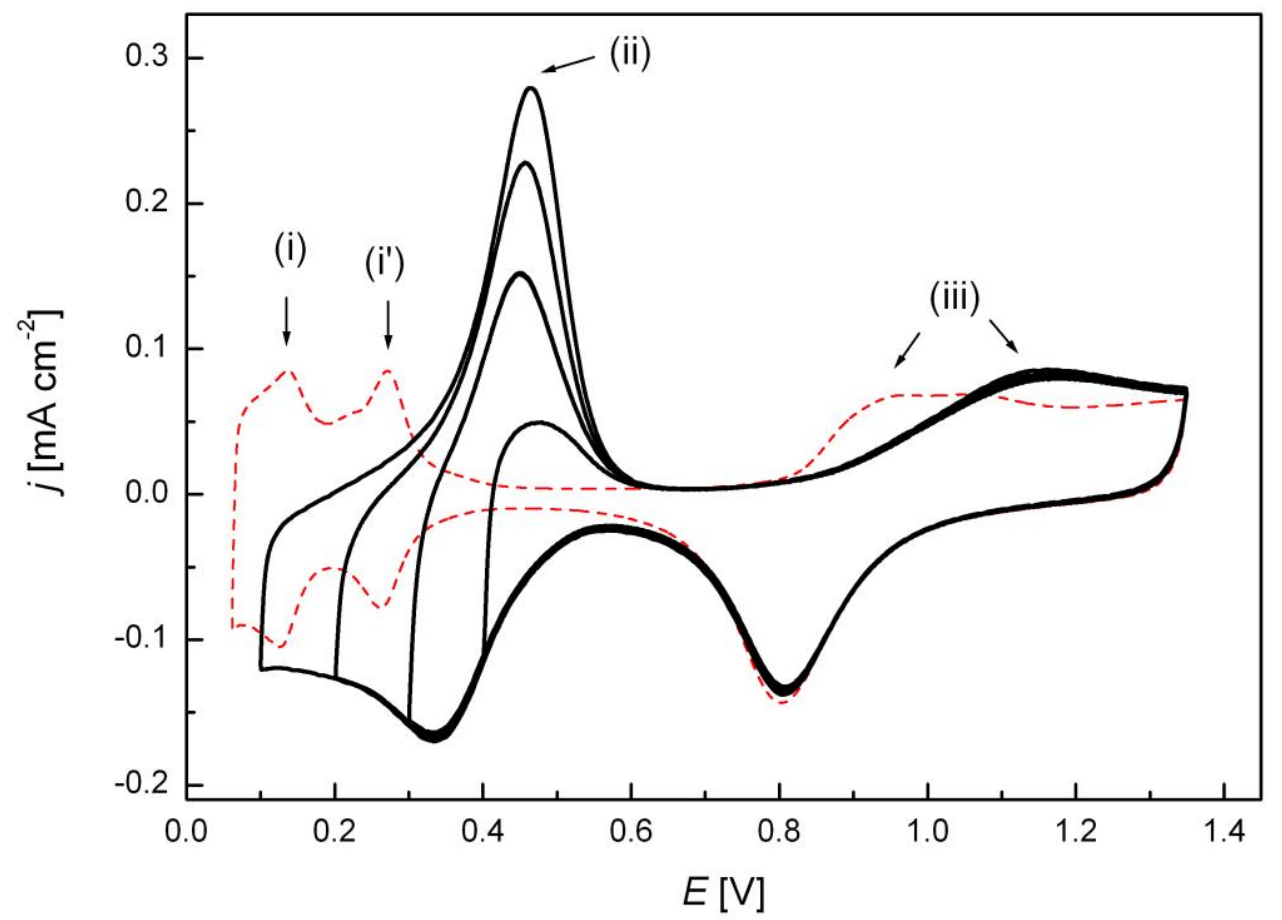

Fig. 1. Cyclic voltammograms of a smooth Pt electrode in $5 \times 10^{-4} \mathrm{M} \mathrm{Mo}(\mathrm{VI})$ containing 0.5 $\mathrm{M} \mathrm{H}_{2} \mathrm{SO}_{4}$ with different cathodic potential limits (400, 300, 200, $100 \mathrm{mV}$ ). Dashed line: $\mathrm{CV}$ of the Pt electrode in $0.5 \mathrm{M} \mathrm{H}_{2} \mathrm{SO}_{4}$, sweep rate: $50 \mathrm{mV} / \mathrm{s}$. Marks of the anodic peaks: (i), (i') oxidation of weakly and strongly bonded hydrogen, respectively, (ii) - oxidation of Mo surface species, (iii) - oxygen adsorption on Pt.

It can be also noticed that during the electrodeposition of Mo-species onto the platinum electrode the position of the oxidation current peak usually attributed to platinum oxide formation (iii), above $800 \mathrm{mV}$, is also influenced. The onset potential of this (iii) peak is shifted to more positive potential than that observed on pure platinum electrode. 


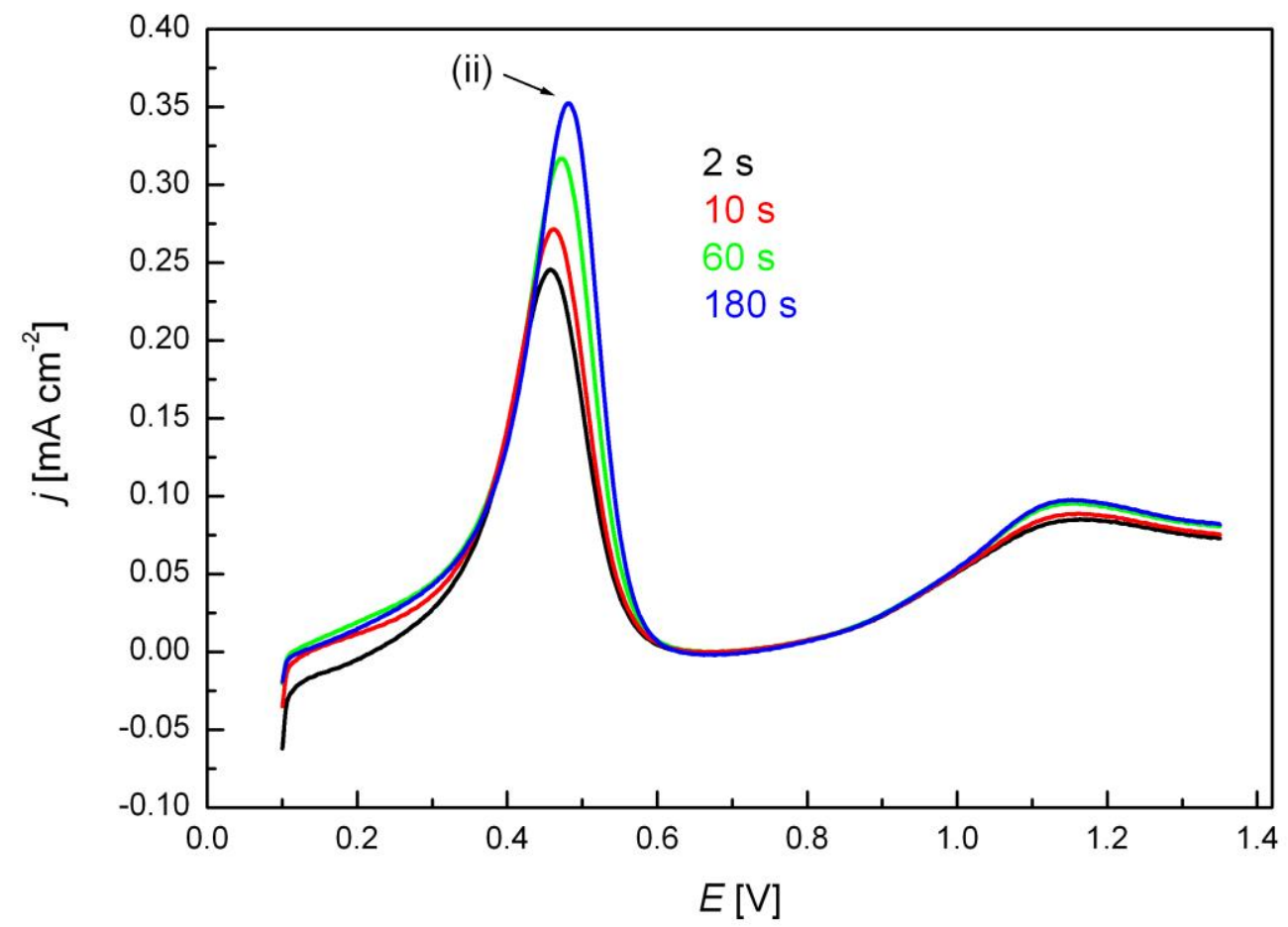

Fig. 2. Linear potential sweep of a smooth Pt electrode in $5 \times 10^{-4} \mathrm{M} \mathrm{Mo}(\mathrm{VI})$ containing 0.5 $\mathrm{M} \mathrm{H}_{2} \mathrm{SO}_{4}$ electrolyte after potentiostatic Mo-deposition at $100 \mathrm{mV}$ for 2, 10, 60 and $180 \mathrm{~s}$. Sweep rate: $50 \mathrm{mV} / \mathrm{s}$. (ii) - Oxidation peak of Mo surface species.

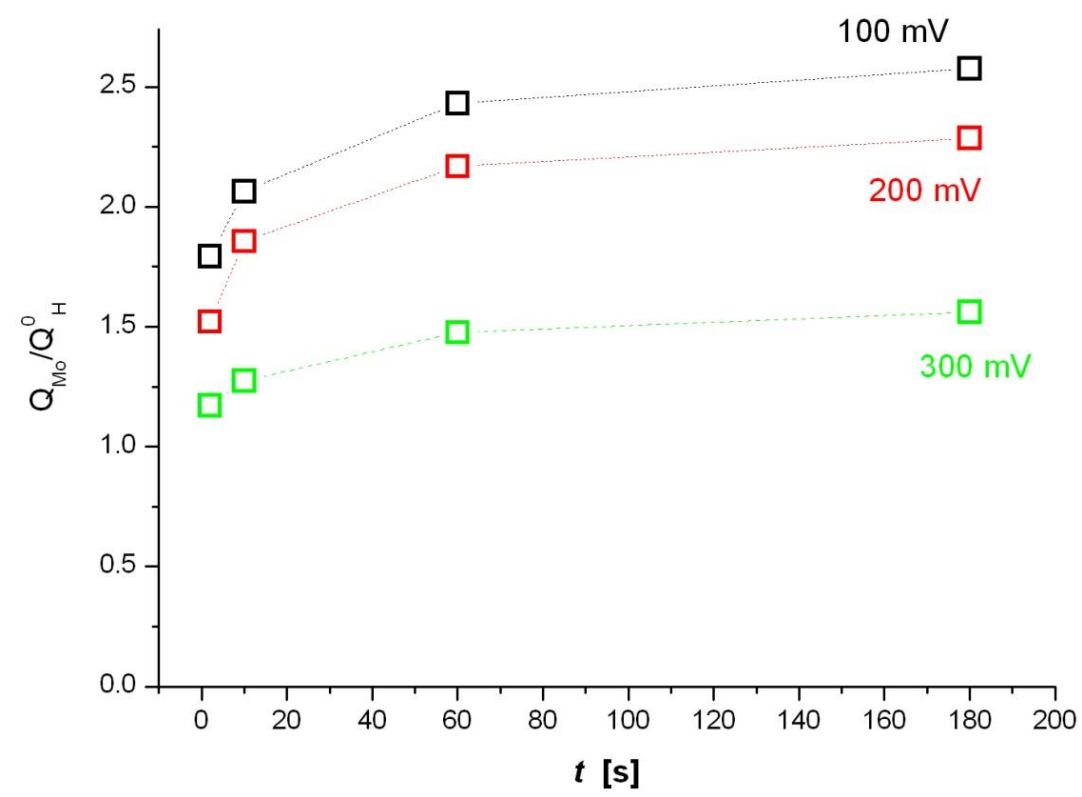

Fig. 3. $\mathrm{Q}_{\mathrm{Mo}} / \mathrm{Q}^{0}{ }_{\mathrm{H}}$ ratio as a function of deposition time of Mo at different potentials. 
By adding various ions (e.g. $\mathrm{Cl}^{-}$) to the $0.5 \mathrm{M} \mathrm{H}_{2} \mathrm{SO}_{4}$ electrolyte solution similar shift of the above mentioned peak was observed [58,59], which could serve as a possible explanation for the observed phenomenon in our case (however, this phenomenon is out of the scope of this paper and shall not be discussed here).

As shown in Fig. 2 in the case of potentiostatic Mo-deposition at $100 \mathrm{mV}$ the magnitude of the oxidation current peak (ii) observed at $450 \mathrm{mV}$ depends on the duration of the deposition. Increasing the time of deposition resulted in increase of the Mo-oxidation peak (ii) at $450 \mathrm{mV}$ (i.e. the amount of the deposit). However, the rate of this increase was reduced with the time of deposition, and the amount of deposit tended towards a saturation value at all investigated potentials, as can be seen in Fig 3, where the charge of the Mo-oxidation peak is normalized to the charge of the adsorbed hydrogen of the bare Pt.

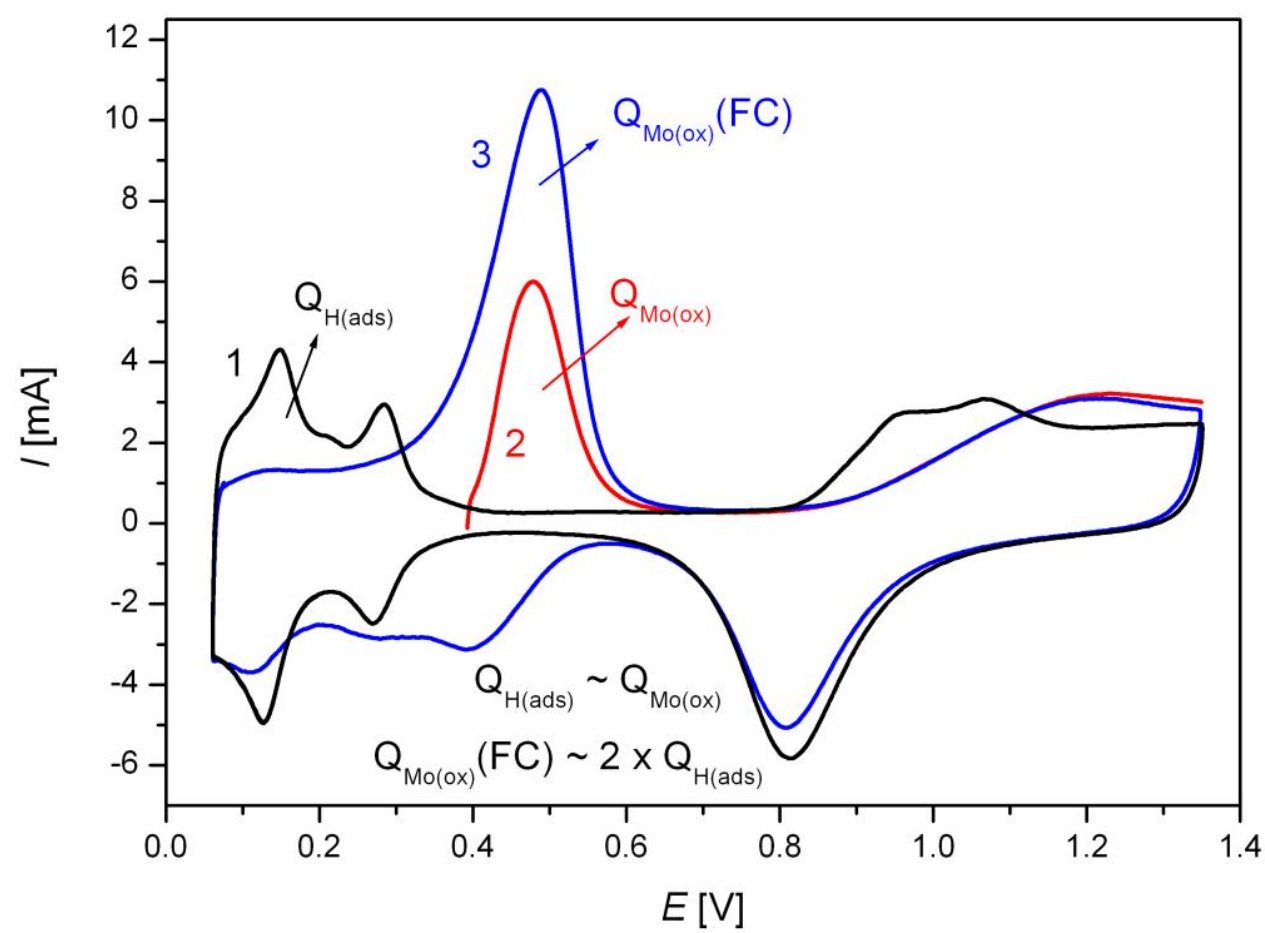

Fig. 4. Cyclic voltammogram of a Pt/Pt electrode in $0.5 \mathrm{M} \mathrm{H}_{2} \mathrm{SO}_{4}$ (curve 1). Linear potential sweep of the same electrode after Mo deposition via oxidation of preadsorbed hydrogen (curve 2) and after Mo-deposition at $50 \mathrm{mV}$ for $5 \mathrm{~min}$ (curve 3). Sweep rate: $10 \mathrm{mV} / \mathrm{s}$.

$\mathbf{Q}_{\mathbf{H}(\text { ads): }}$ oxidation charge of adsorbed hydrogen; $\mathbf{Q}_{\mathbf{M o ( o x})}$ : oxidation charge of surface Mospecies; $\mathbf{Q}_{\mathbf{M o ( o x})}(\mathbf{F C})$ : oxidation charge of surface Mo-species in the case of full coverage. 
In order to obtain more reliable data about the relative amount of Mo-deposit platinized platinum $(\mathrm{Pt} / \mathrm{Pt})$ electrode was used in the following experiments (in the case of larger real surface area the role of disturbing factors -for example, small amount of impuritiescan be decreased).

$\mathrm{CV}$ of the Pt/Pt electrode and linear potential sweep after Mo deposition via oxidation of preadsorbed hydrogen are shown on Fig. 4 (curves $\mathbf{1}$ and 2, respectively).

As a first step of this experiment the $\mathrm{Pt} / \mathrm{Pt}$ electrode was saturated with adsorbed hydrogen in pure $\mathrm{H}_{2} \mathrm{SO}_{4}$ electrolyte, then $\mathrm{Mo}(\mathrm{VI})$ ions were introduced into the main compartment of the cell under open circuit conditions (potential was: $50 \mathrm{mV}$ ). Adsorbed hydrogen, as a reducing agent, reacted with Mo(VI) leading to deposition of Mo-species in an amount equivalent to the charge transfer from hydrogen. It can be mentioned that the potential of the electrode as a result of this process rose to $390 \mathrm{mV}$ in 5 minutes. As indicated on Fig. 4 the amount of the oxidation charge of surface deposited Mo-species $\left(\mathrm{Q}_{\mathrm{Mo}(\mathrm{ox})}\right)$ was equal to that of the hydrogen adsorption/desorption $\left(\mathrm{Q}_{\mathrm{H}(\mathrm{ads})}\right)$. This means that the deposition of Mo species from the Mo(VI)-solution and the oxidation of the deposit take place without loss of charge, the same amount of charge was needed for the oxidation as it was available for the deposition. Thus, it has been proven that all of the product of the reduction remained on the surface and did not desorbed into the electrolyte.

Linear potential sweep of the Mo-Pt/Pt electrode after potentiostatic Mo-deposition for $5 \mathrm{~min}$ at $50 \mathrm{mV}$ potential corresponding to full coverage can be also seen in Fig 4 (curve 3). It is known that initiation of Mo-containing electrode at $50 \mathrm{mV}$ is sufficient to reduce $\mathrm{Mo}^{6+}$ to $\mathrm{Mo}^{4+}$ [60]. At full coverage considerable increase of the peak corresponding to the Mo oxidation reaction is obvious $\left(\mathrm{Q}_{\mathrm{Mo}(\mathrm{ox})}(\mathrm{FC}) \sim 2 \times \mathrm{Q}_{\mathrm{H}(\mathrm{ads})}\right)$. Thus, the change of the oxidation state of the molybdenum during Mo-deposition at $50 \mathrm{mV}$ for $5 \mathrm{~min}$ from $6+$ to $4+$ can be proposed. Oxidation of the deposited Mo monolayer requires twice as much charge than oxidation of adsorbed hydrogen, which suggests a probable $\mathrm{Mo}^{6+} \rightarrow \mathrm{Mo}^{4+}$ transition upon deposition and $\mathrm{a} \mathrm{Mo}^{4+} \rightarrow \mathrm{Mo}^{6+}$ transition upon oxidation.

According to the literature [13] the comparison with Pourbaix diagram for Mo confirms that the oxidation peak around $450 \mathrm{mV}$ is due to the $\mathrm{Mo}^{4+} \rightarrow \mathrm{Mo}^{6+}$ transition. In Ref. [61] the number of electrons involved in the redox reaction calculated from the Mo redox peak pair of $\mathrm{CV}$ s recorded at slow sweep rates for the $\mathrm{Pt} / \mathrm{MoO}_{\mathrm{x}} / \mathrm{C}$ system was also in a good agreement with assignment of this system to $\mathrm{MoO}_{2} / \mathrm{MoO}_{3}$. 


\subsection{Stability of the adsorbed Mo-species}

In the next set of experiments the stability of the adsorbed surface Mo-species was studied.
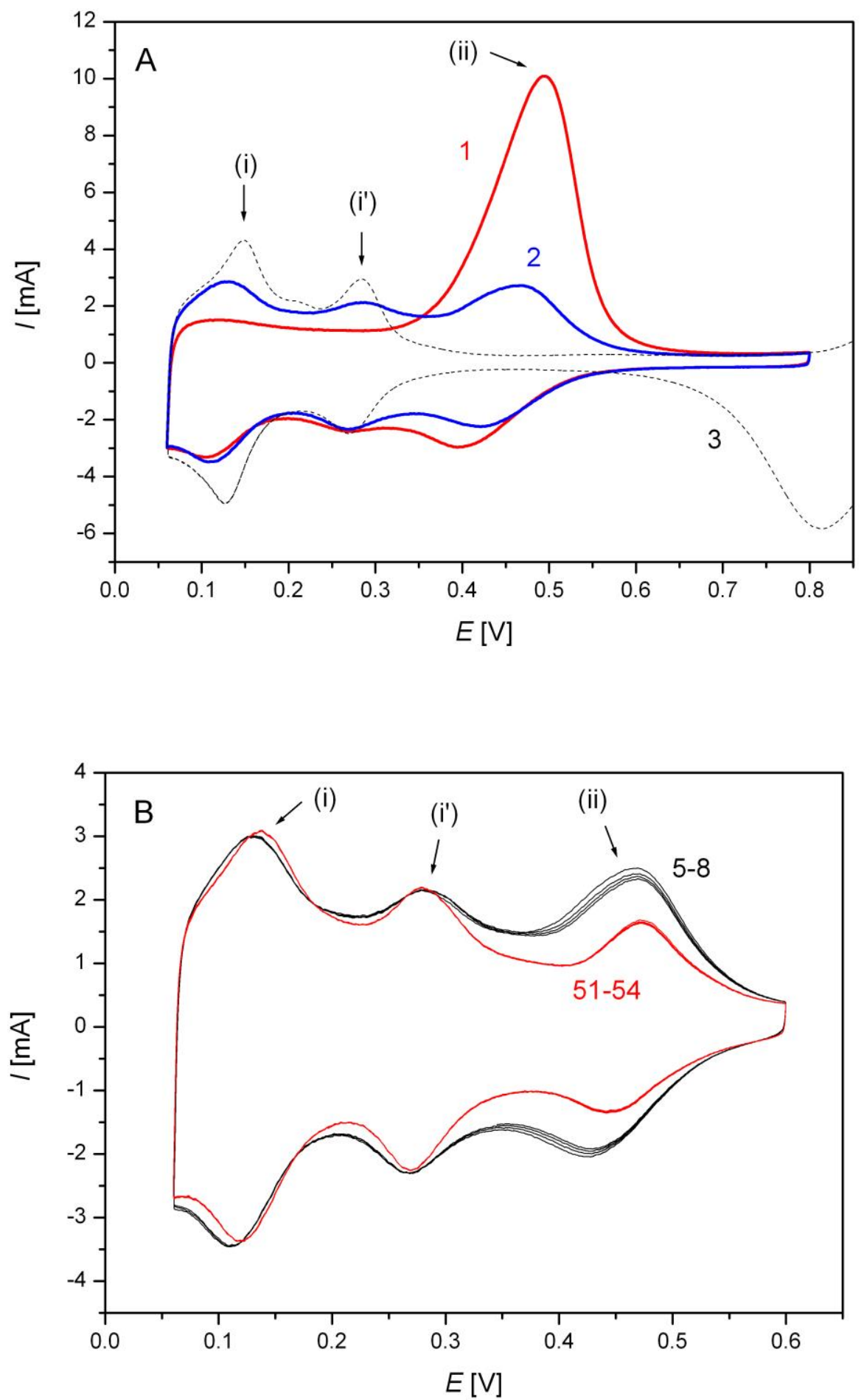

Fig. 5. (A) Cyclic voltammograms of a Mo-Pt/Pt electrode after Mo-deposition at $50 \mathrm{mV}$ for 5 min; CVs were measured in pure Mo-free $0.5 \mathrm{M} \mathrm{H}_{2} \mathrm{SO}_{4}$. Curve 1: 1st cycle, curve 2: 3rd 
cycle, curve 3 (dashed line): $\mathrm{CV}$ of the bare $\mathrm{Pt} / \mathrm{Pt}$ electrode in $0.5 \mathrm{M} \mathrm{H}_{2} \mathrm{SO}_{4}$. (B) Continuation of the cyclic polarization of the Mo-Pt/Pt electrode in $0.5 \mathrm{M} \mathrm{H}_{2} \mathrm{SO}_{4}$. Numbers of the cycles are indicated. Marks of the anodic peaks: (i), (i') - oxidation of weakly and strongly bonded hydrogen, respectively, (ii) - oxidation of Mo surface species.

After Mo deposition at $50 \mathrm{mV}$ the electrolyte was changed and CVs were recorded in pure Mo-free $\mathrm{H}_{2} \mathrm{SO}_{4}$ electrolyte. As shown in Fig. 5.A after the first cycle a significant decrease of the current peak (ii) at $450 \mathrm{mV}$ could be observed (see curve 2 in Fig. 5.A). This behavior was accompanied with some restoration of the hydrogen adsorption/desorption peaks (i, i'), indicating that certain part of the monolayer Mo-deposit has been desorbed during the first potential cycle. However the $25-30 \%$ of the Pt surface remained covered after the first cycle, and the cathodic pair of the Mo oxidation peak (ii) indicates that the oxidized Mo can be reduced. Continuing the cyclic polarization this strongly adsorbed part of the Mooxide proved to be quite stable, as demonstrated by the 5-8 and 51-54 cycles on Fig. 5.B. As seen from Fig. 5.B prolonged polarization cycling results in only small decrease of the Mo deposit (ii). Thus, even after oxidation into the 6+ state a certain part (20-25\%) of the initial Mo monolayer irreversibly deposited on the Pt/Pt electrode remains stable on the surface even after prolonged cyclic polarization; this Mo surface species can be reduced back into the 4+ state even after polarization up to $1000 \mathrm{mV}$. It is necessary to mention that the amount of deposited Mo depends on the applied potential but never exceeds a monolayer, thus Pt-Mo bonds stabilize the deposited Mo.

The stability of Mo-containing Pt electrocatalysts is still under debate in the existing literature. Irreversible Mo loss from the electrode surface has been previously reported in the literature $[22,60,62]$, which was attributed to the formation of Mo species soluble in acid solution. In Ref. [63] the fact of Mo dissolution has been confirmed in a test with a smooth Pt electrode immersed into the working electrolyte. A peak at ca. $450 \mathrm{mV}$, very characteristic to the presence of Mo species in the system, appears on the CV of the Pt test electrode after a few cycles of the working Pt-Mo/C electrode. At the same time, much inhibited dissolution of Mo from the Pt-Mo alloys was attributed to the stabilization effect of the alloying with $\mathrm{Pt}$ [13]. Our own observations also suggest that Mo species adsorbed at certain locations are particularly strongly bound and cannot be easily oxidized into dissolvable species. In this aspect it may be interesting to note that theoretical calculations of Wang et al. [64] predicted a non-uniform distribution of $\mathrm{Pt}$ on $\mathrm{Mo}$ atoms in the outermost atomic layer in $\mathrm{Pt}_{80} \mathrm{Mo}_{20}$ 
nanoparticles: the Pt atoms segregate preferentially to the facet sites, while Mo atoms favor the low coordination edge and vertex sites, alternating with Pt whenever possible.

\subsection{Behaviour of the Mo-Pt/Pt electrode in the presence of $\mathrm{CO}$}

In our recent study it has been demonstrated [54] that the oxidation of $\mathrm{CO}$ on the Mocontaining Pt-based catalyst commences at exceptionally low potential values (ca. $100 \mathrm{mV}$ ). We demonstrated [54] that the CO stripping voltammograms of the $\mathrm{Pt} / \mathrm{Ti}_{(1-\mathrm{x})} \mathrm{Mo}_{\mathrm{x}} \mathrm{O}_{2}-\mathrm{C}(\mathrm{x}=0.2-$ 0.4) catalysts display two clear oxidation features: (i) the main anodic peak at $705 \mathrm{mV}$, and (ii) two small overlapping "pre-peaks" centered at ca. 215 and $400 \mathrm{mV}$, which may be attributed to partial oxidation of weakly adsorbed $\mathrm{CO}$ and oxidation of Mo surface species, respectively.

Behaviour of the model catalytic surfaces prepared by in situ electrochemical deposition of molybdenum oxide on platinized platinum electrodes in the presence of $\mathrm{CO}$ is demonstrated in Fig. 6.A. Four consecutive cyclic voltammograms of Mo-Pt/Pt electrode with Mo coverage of about $25 \%$ in $\mathrm{CO}$ saturated and $\mathrm{CO}$-purged $\mathrm{H}_{2} \mathrm{SO}_{4}$ electrolyte were recorded between 50 and $550 \mathrm{mV}$ with low sweep rate $(0.5 \mathrm{mV} / \mathrm{s})$. Considering the very low sweep rate the current values can be regarded as representation of quasi-stationer states.

As shown in Fig. 6.A during the first sweep in $\mathrm{CO}$ saturated $\mathrm{H}_{2} \mathrm{SO}_{4}$ significant oxidation current in the anodic scan was observed. In this case the oxidation of CO takes place at very low potential (the onset potential $\mathrm{E}_{\mathrm{CO} \text {,onset }}<100 \mathrm{mV}$ ). Thus the irreversibly adsorbed Mo partial monolayer is enough to change significantly the $\mathrm{CO}$ poisoning properties of the Pt surface. However, in the second and during the subsequent cycles in this potential range pronounced decrease of the anodic current was observed. The pre-oxidation peak completely disappeared in the fourth cycle (see curve 4 in Fig. 6.A).

Thus, the CO tolerance of the Mo-Pt/Pt electrode was totally lost after the third sweep of the cyclic polarization from $50 \mathrm{mV}$ to $550 \mathrm{mV}$. Since the upper potential limit $550 \mathrm{mV}$ is higher than the potential needed for the $\mathrm{Mo}(\mathrm{IV}) \rightarrow \mathrm{Mo}(\mathrm{VI})$ transition, this observation suggests that only Pt modified by $\mathrm{Mo}(\mathrm{IV})$ species is active in the low-potential $\mathrm{CO}$ oxidation reaction (LPCOR). Despite the fact that after oxidizing to the 6+ state Mo remains on the Pt surface, LPCOR is not observable. This behavior is in analogy with that found previously for $\mathrm{Pt} / \mathrm{Ti}_{(1-}$ ${ }_{\mathrm{x}} \mathrm{Mo}_{\mathrm{x}} \mathrm{O}_{2}-\mathrm{C}$ mixed oxide-carbon composite supported catalysts, which also lost their activity in LPCOR when Mo had become fully oxidized (above ca. $400 \mathrm{mV}$ ) and re-reduction of these oxidized species was hindered when strongly adsorbed carbonyl species were still present. 

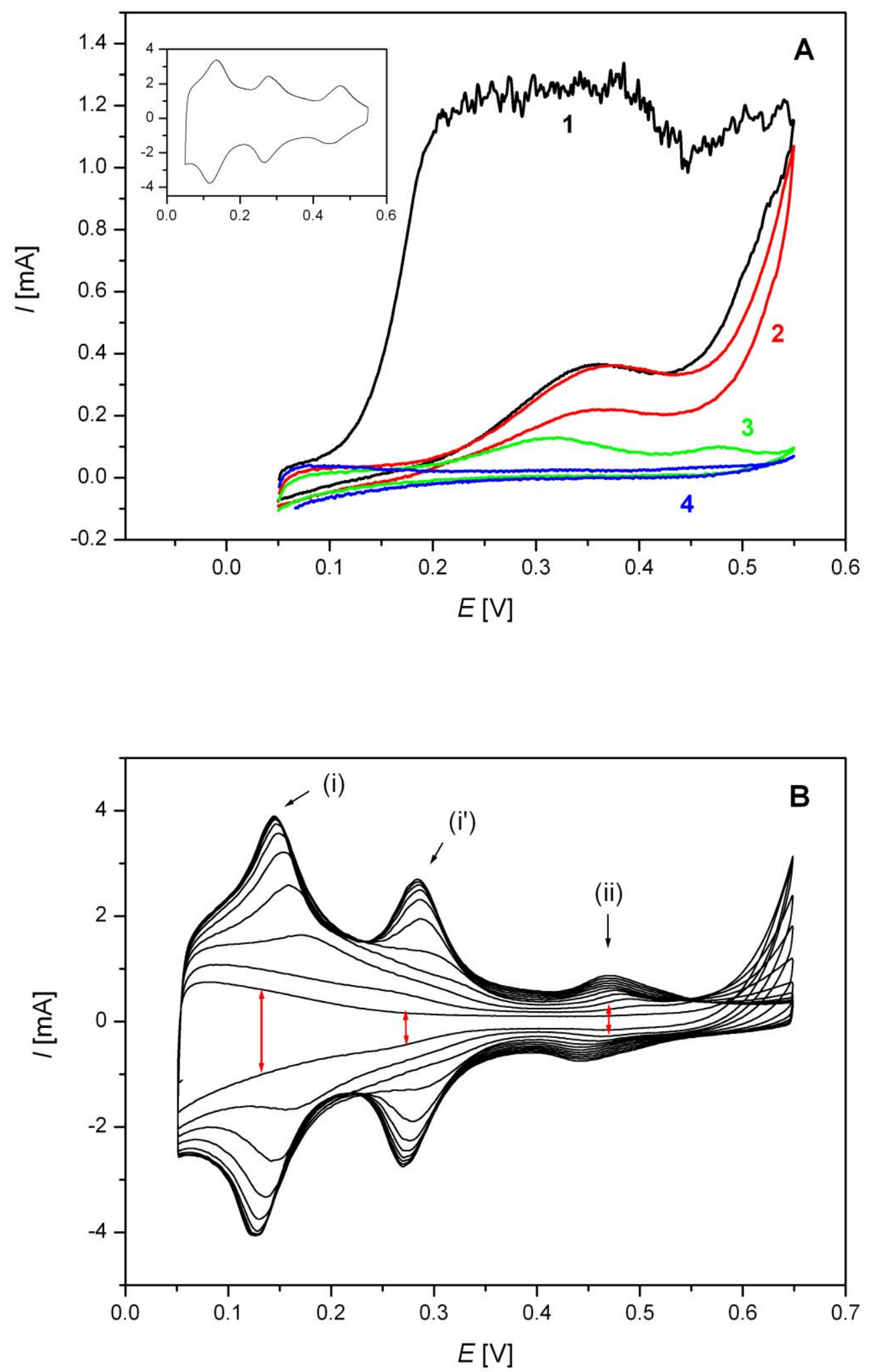

Fig. 6. (A) Cyclic voltammograms of Mo-Pt/Pt electrode (Mo coverage is about 25\%) with low sweep rate $(0.5 \mathrm{mV} / \mathrm{s})$ in $\mathrm{CO}$ saturated and $\mathrm{CO}$-purged $0.5 \mathrm{M} \mathrm{H}_{2} \mathrm{SO}_{4}$. Numbers indicate the number of cycles. Insert: $\mathrm{CV}$ of the same electrode in Ar-purged $\mathrm{H}_{2} \mathrm{SO}_{4}$ with $10 \mathrm{mV} / \mathrm{s}$ 
sweep rate. (B) Cyclic voltammogtrams of the CO-covered Mo-Pt/Pt electrode in pure Arpurged $0.5 \mathrm{M} \mathrm{H}_{2} \mathrm{SO}_{4}$. Red colored arrows indicate the direction of changes. Marks of the anodic peaks: (i), (i') - oxidation of weakly and strongly bonded hydrogen, respectively, (ii) oxidation of Mo surface species.

In the case of the composite supported electrocatalysts oxidized Mo species can be rereduced and the activity in the LPCOR can be restored only if the platinum surface is COfree. If $\mathrm{Pt}$ is largely covered by $\mathrm{CO}$, reduction of $\mathrm{Mo}(\mathrm{VI})$ into $\mathrm{Mo}(\mathrm{IV})$ does not occur. It means that reduction of these Mo(VI) species requires an abundant source of hydrogen in the form of hydrogen spillover and/or charge transfer from Pt particles released from CO [65]. Note that, $\mathrm{CO}_{\mathrm{ads}}$ species can be completely removed only above $550 \mathrm{mV}$ (above the so called pre-peak potential).

In order to explore the relation between the presence of strongly bound $\mathrm{CO}$ adsorbates and the reduction behavior of the mentioned Mo(VI) species in case of the Mo-Pt model system, in the next set of experiments the upper potential limit of the polarization was set to $650 \mathrm{mV}$, where oxidation of a fraction of the $\mathrm{CO}$ species left on the Pt surface after the previous scans limited to $550 \mathrm{mV}$ is expected. Fig. 6.B illustrates the influence of the number of the polarization cycles to $650 \mathrm{mV}$ on the change of the electrochemical behaviour of the $\mathrm{Mo}-\mathrm{Pt} / \mathrm{Pt}$ electrode in pure CO-free solution.

After measuring the 1-4 curves presented in Fig. 6.A, Ar was bubbled through the main compartment of the cell and $20 \mathrm{CVs}$ were recorded again in the CO-free electrolyte solution. Already in the $2^{\text {nd }}-3^{\text {rd }}$ cycles the appearance of the peaks corresponding to the adsorption/desorption of weakly bonded hydrogen (i) on the Pt surface and appearance of the Mo redox peaks (ii) were observed. In the $4^{\text {th }}$ cycle the peaks of the adsorption/desorption of strongly bonded hydrogen (i') were also recovered. This experiment reveals that partial oxidation of strongly adsorbed CO starts via slight increase of the potential limit up to 650 $\mathrm{mV}$ and subsequently the strongly oxidized surface Mo species (ii) can be re-reduced.

Fig. 7.A compares the $\mathrm{CVs}$ of a $\mathrm{Pt} / \mathrm{Pt}$ electrode recorded in $0.5 \mathrm{M} \mathrm{H}_{2} \mathrm{SO}_{4}$ solutions with and without $5 \times 10^{-4} \mathrm{M} \mathrm{Mo}(\mathrm{VI})$ precursor compound. As described earlier and shown in Fig. 7.A a characteristic feature of the $\mathrm{CV}$ of the Mo-Pt/Pt electrode (see curve 2) is the appearance of the Mo redox peak pair (ii) in the double layer region compared to the $\mathrm{CV}$ of $\mathrm{Pt} / \mathrm{Pt}$. From this comparison it is obvious that after deposition of Mo-species slight decrease of the hydrogen adsorption/desorption peaks (i) and (i') was also observed. 


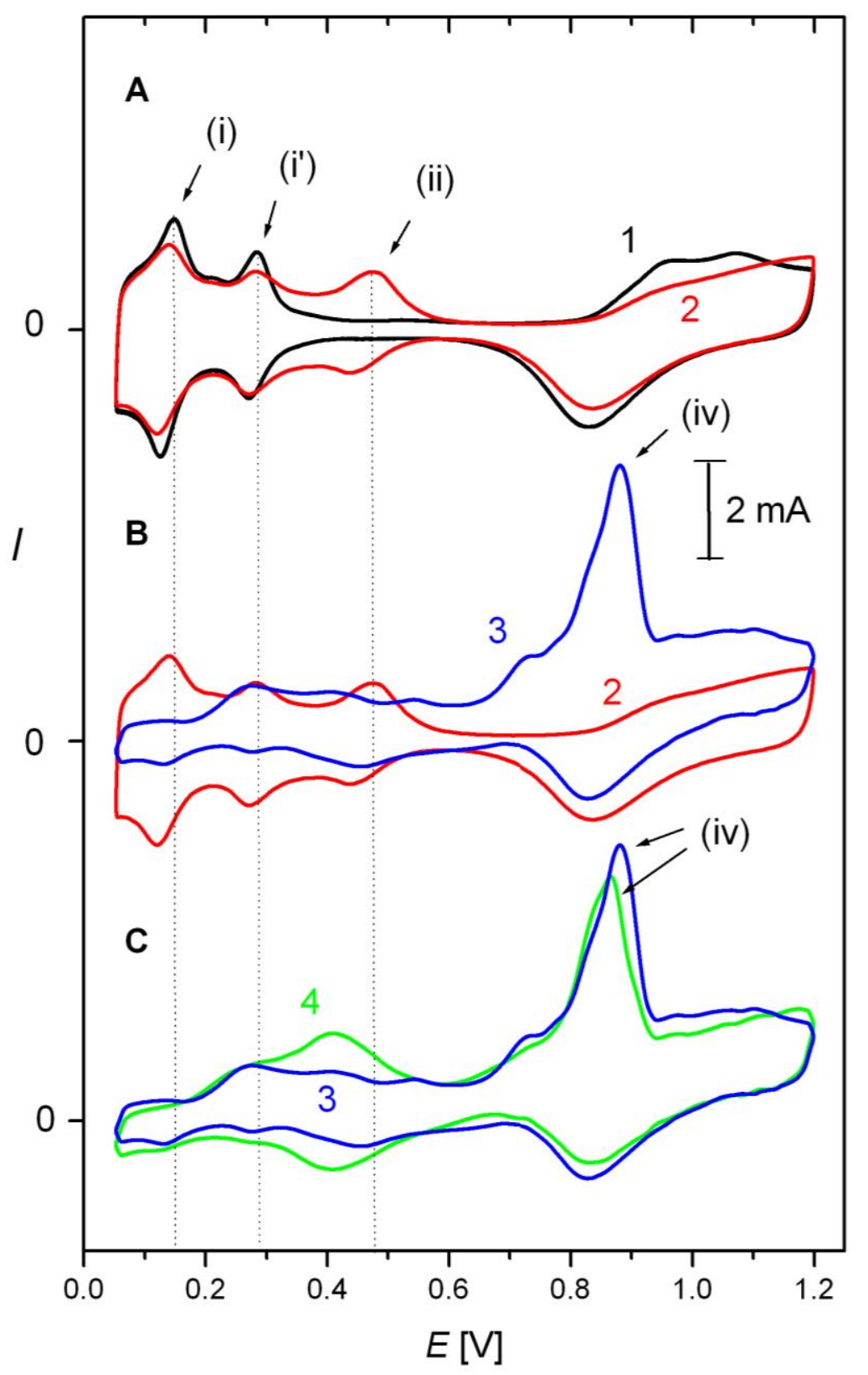

Fig. 7. Cyclic voltammogram of a $\mathrm{Pt} / \mathrm{Pt}$ electrode recorded in $0.5 \mathrm{M} \mathrm{H}_{2} \mathrm{SO}_{4}$ (curve 1), in $5 \mathrm{x}$ $10^{-4} \mathrm{M} \mathrm{Mo}(\mathrm{VI})$-containing $0.5 \mathrm{M} \mathrm{H}_{2} \mathrm{SO}_{4}$ (curve 2), in $5 \times 10^{-4} \mathrm{M} \mathrm{Mo}(\mathrm{VI})$-containing and COsaturated $\mathrm{H}_{2} \mathrm{SO}_{4}$ (curve 3), in $10^{-3} \mathrm{M} \mathrm{Mo}\left(\mathrm{VI}\right.$ )-containing and $\mathrm{CO}$-saturated $0.5 \mathrm{M} \mathrm{H}_{2} \mathrm{SO}_{4}$ (curve 4). Sweep rate $10 \mathrm{mV} / \mathrm{s}$. Marks of the anodic peaks: (i), (i') - oxidation of weakly and strongly bonded hydrogen, respectively, (ii) - oxidation of Mo surface species, (iv) - oxidation of strongly adsorbed CO. 
This behaviour is in accordance with the presence of some amount of Mo irreversibly deposited on the $\mathrm{Pt} / \mathrm{Pt}$ electrode surface.

Fig. 7.B reveals the changes observed in the shape of the CVs of the Mo-Pt/Pt electrode before (curve 2) and after saturation the electrolyte with CO (curve 3). Since in COsaturated electrolyte $\mathrm{CO}$ blocks the platinum catalytic sites the hydrogen adsorption/desorption peaks (i) and (i') are not observed (see curve 3 in Fig. 7.B). The voltammogram of the Mo-Pt/Pt electrode recorded in CO-saturated electrolyte displays usual oxidation features corresponding to the Mo-containing Pt catalysts: the main anodic peak (iv) and several small overlapping "pre-peaks" between 200 and $600 \mathrm{mV}$ (curve 3). In our recent study [54] these pre-oxidation peaks were attributed to oxidation of both weakly adsorbed CO and Mo surface species (ii).

However, it is necessary to mention that the position of the main anodic peak (iv) observed on the model Mo-Pt/Pt electrode is shifted by ca. $150 \mathrm{mV}$ toward more positive potentials comparing to the $\mathrm{Pt} / \mathrm{Ti}_{(1-\mathrm{x})} \mathrm{Mo}_{\mathrm{x}} \mathrm{O}_{2}-\mathrm{C}(\mathrm{x}=0.2-0.4)$ catalysts [54]. According to the literature and our recent studies $[39,54,65]$ this peak can be assigned to the electrooxidation of strongly bound $\mathrm{CO}$.

Comparison of the $\mathrm{CO}_{\text {ads }}$ electrooxidation behaviors of the Mo-Pt/Pt electrode with different amount of surface deposited Mo species (compare curves $\mathbf{3}$ and $\mathbf{4}$ in Fig. 7.C) demonstrates an increased $\mathrm{CO}$ tolerance of the Mo-Pt/Pt electrode with higher Mo content. As shown in Fig. 7.C the position of the main anodic peak (iv) corresponding to the electrooxidation of strongly bounded $\mathrm{CO}$ for Mo-Pt/Pt electrode with increased Mo content shifts toward less positive potential values in comparison with that electrode obtained by using $5 \times 10^{-4} \mathrm{M}$ Mo precursor compound. Moreover, it is necessary to mention that the behaviors of the Mo-Pt/Pt electrode with higher Mo content strongly resembles to that observed in our earlier study over Mo-containing composite supported Pt catalysts [54].

\subsection{Ex situ photoelectron spectroscopy analysis}

In order to obtain further information on the properties of the Mo deposits on the $\mathrm{Pt}$ electrodes, ex situ X-ray photoelectron spectroscopy experiments were carried out on samples prepared by saturating of the smooth policrystalline platinum electrode surface with Mo at 50 $\mathrm{mV}$. After the Mo deposition the platinum foil was taken out from the electrochemical cell at $50 \mathrm{mV}$ (see curve (a) on Fig. 8) or a part of the Mo overlayer was removed by polarizing to $600 \mathrm{mV}$ (curve (b) on Fig. 8) or $1000 \mathrm{mV}$ before removal (curve (c) on Fig. 8). In order to 
avoid undesired oxidation, the samples were carried to the photoelectron spectrometer under water; nevertheless, a few minutes exposure to ambient conditions was unavoidable.

Fig. 8.A shows the XPS spectra of the Mo 3d region at the beginning of the data collection. Irrespective to the preparation conditions, in all three samples $\mathrm{Mo}^{6+}$ and $\mathrm{Mo}^{5+}$ ionic states were observed with leading contributions around 232.5 and $231.1 \mathrm{eV}$ binding energies [66]. Assuming that some oxidation may easily occur during sample transfer, the presence of a strong $\mathrm{Mo}^{5+}$ contribution in the spectrum of the Mo-saturated sample is in agreement with the proposed reductive deposition as described in the electrochemical results. The XPS data confirm that a certain fraction of the adsorbed Mo species remain on the Pt surface even after polarization to $1000 \mathrm{mV}$. Somewhat surprisingly, in both cases of oxidative removal of the dissolvable Mo, the ex situ XPS measurement reveals the presence of a mixture of $\mathrm{Mo}^{6+}$ and $\mathrm{Mo}^{5+}$ states.
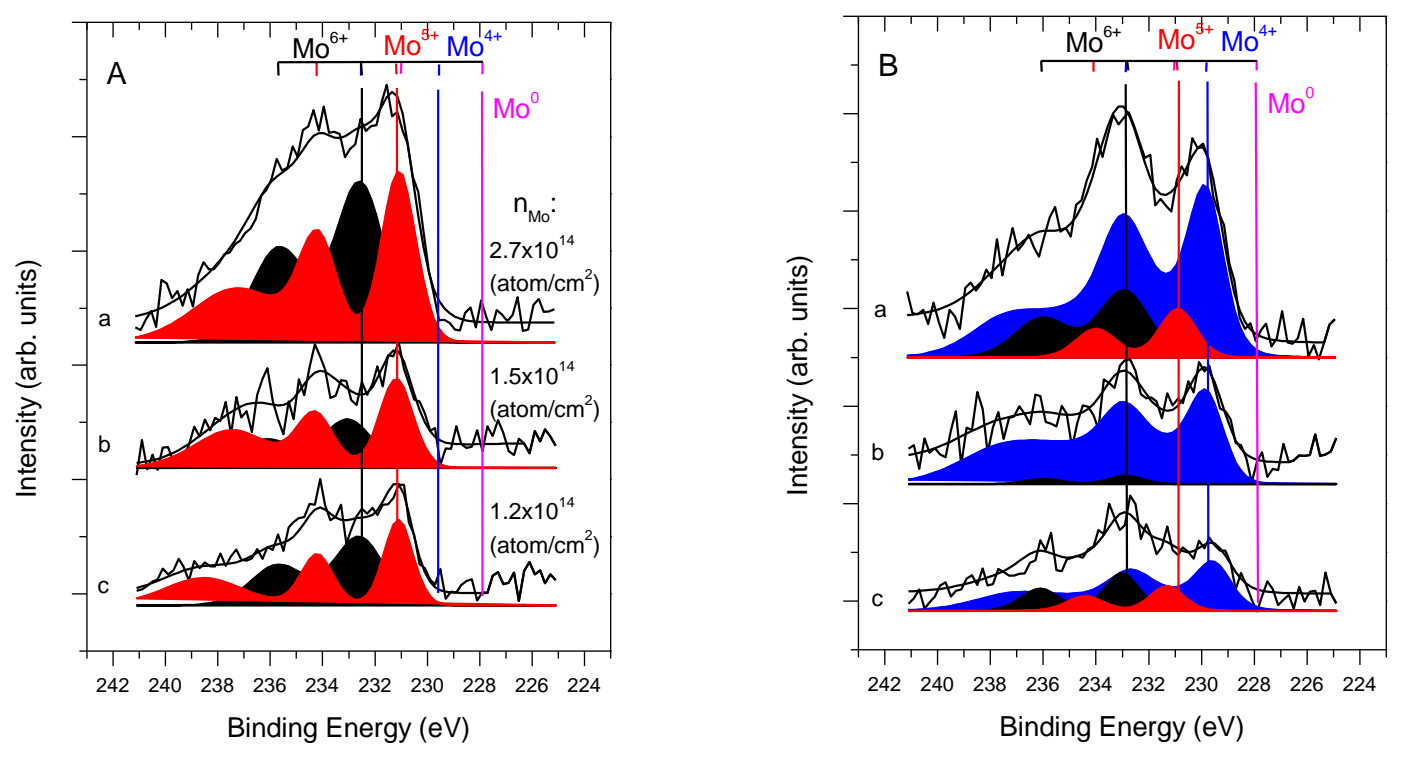

Fig. 8. Mo $3 \mathrm{~d}$ spectra of the $\mathrm{Mo} / \mathrm{Pt}$ model samples at the beginning of the data collection (A) and after $1 \mathrm{~h}$ exposure to the X-ray radiation in the electron spectrometer (B). Curve (a): after deposition of Mo up to the saturation coverage at $50 \mathrm{mV}$; (b) after removing of dissolvable Mo at $600 \mathrm{mV}$; (c) after removing of dissolvable Mo at $1000 \mathrm{mV}$. Numbers in panel A indicate the estimated surface concentration of Mo.

The easily reversible oxidation of the adsorbed Mo species is indicated by the very pronounced radiation sensitivity of the Mo spectra. As shown in Fig. 8.B $1 \mathrm{~h}$ exposition to the $\mathrm{X}$-ray radiation transforms a significant part of the higher Mo oxides into the $\mathrm{Mo}^{4+}$ state, 
which has a leading peak slightly below $230 \mathrm{eV}$ binding energy. The $\mathrm{Mo}^{4+}$ state is characterized by a complex line shape due to differently screened final states $[67,68]$; the line shape used here was derived from measurements on $\mathrm{MoO}_{2}$ [54]. According to our observations, the sample obtained by polarization to $1000 \mathrm{mV}$ resists somewhat more to reduction by $\mathrm{X}$-ray exposure.

Quantitative evaluation of the Mo and Pt peak intensity data gives an estimation on the surface concentration of Mo ions. According to these data, the saturation amount of deposited Mo is around 0.2 monolayer ( 1 monolayer is around $1.3 \times 10^{15}$ atom $/ \mathrm{cm}^{2}$, corresponding to the surface atomic density of polycrystalline $\mathrm{Pt}$ ). The polarization treatment indeed significantly decreases the surface concentration of Mo and after oxidation at $1000 \mathrm{mV}$ less than $0.1 \mathrm{ML}$ Mo remains on the Pt.

\section{Conclusions}

Model Pt-Mo catalytic surfaces were prepared using electrochemical and electroless deposition of molybdenum at potential below $500 \mathrm{mV}$ onto smooth polycrystalline $\mathrm{Pt}$ and $\mathrm{Pt} / \mathrm{Pt}$ electrodes. According to the results of the electrochemical measurements there was correlation between the applied potential and the amount of deposited Mo, which never exceeded a monolayer, thus Pt-Mo bonds stabilize the deposited Mo oxide. Since the hydrogen adsorption and desorption peaks of the platinum disappear it has been concluded that the deposited product totally covered the platinum surface. Electrochemical data indicated that at full coverage oxidation of the deposited Mo monolayer requires twice as much charge as needed for oxidation of adsorbed hydrogen, which suggests a probable $\mathrm{Mo}^{6+} \rightarrow \mathrm{Mo}^{4+}$ transition upon deposition and a $\mathrm{Mo}^{4+} \rightarrow \mathrm{Mo}^{6+}$ transition upon oxidation. In line with the ex situ XPS findings even after oxidation into the 6+ state a certain part (20-25\%) of the initial Mo monolayer remains irreversibly bound to the Pt surface; this fractional layer remains stable on the surface even after prolonged cyclic polarization. The irreversibly adsorbed Mo surface species can be reduced back into the 4+ state even after polarization up to $1000 \mathrm{mV}$.

It has been demonstrated that this irreversibly deposited Mo partial monolayer is enough to change significantly the $\mathrm{CO}$ poisoning properties of the $\mathrm{Pt}$ surface. On the Mo:Pt (1:4) surface $\mathrm{CO}$ oxidation is initiated at extremely low potentials (ca. $100 \mathrm{mV}$ ). Moreover, only Pt modified by Mo(IV) species is active in low-potential CO oxidation reaction. Despite the fact that after oxidizing to the $6+$ state Mo remains on the Pt surface, low potential CO oxidation becomes hindered in the presence of completely oxidized Mo. Thus, the Pt-Mo 
catalytic surface lost their activity in LPCOR when Mo had become fully oxidized (above ca. $400 \mathrm{mV})$. However, Mo(VI)-oxide remaining on the surface can be reactivated by reduction of molybdenum into the $4+$ oxidation state, but this reduction requires clean, $\mathrm{CO}$-free $\mathrm{Pt}$ surface. If Pt is largely covered by $\mathrm{CO}$, reduction of $\mathrm{Mo}(\mathrm{VI})$ into $\mathrm{Mo}(\mathrm{IV})$ does not occur.

\section{Acknowledgements}

The research within project No. VEKOP-2.3.2-16-2017-00013 was supported by the European Union and the State of Hungary, co-financed by the European Regional Development Fund. Financial support by the OTKA-project [grant number K112034 (István Bakos)] is greatly acknowledged.

\section{References}

[1] Meier JC, Galeano C, Katsounaros I, Topalov AA, Kostka A, Schuüth F, Mayrhofer KJJ (2012) Degradation Mechanisms of Pt/C Fuel Cell Catalysts under Simulated Start-Stop Conditions. ACS Catalysis 2(5):832-843

[2] Mathias MF, Makharia R, Gasteiger HA, Conley JJ, Fuller TJ, Gittleman CI, Kocha SS, Miller DP, Mittelsteadt CK, Xie T, Yan SG, Yu PT (2005) Two Fuel Cell cars in every garage? Electrochem. Soc. Interface 14:24-35

[3] Elezović NR, Gajić-Krstajić LjM, Vračar LjM, Krstajić NV (2010) Effect of chemisorbed $\mathrm{CO}$ on $\mathrm{MoO}_{\mathrm{x}}-\mathrm{Pt} / \mathrm{C}$ electrode on the kinetics of hydrogen oxidation reaction. Int $\mathrm{J}$ Hydrogen Energy 35:12878-12887

[4] Santiago EI, Batista MS, Assaf EM, Ticianelli EA (2004) Mechanism of CO Tolerance on Molybdenum-Based Electrocatalysts for PEMFC. J Electrochem Soc 151(7):A944-A949

[5] Muhamad EN, Takeguchi T, Wang F, Wang G, Yamanaka T, Ueda W (2009) A Comparative Study of Variously Prepared Carbon-Supported Pt/MoO ${ }_{\mathrm{x}}$ Anode Catalysts for a Polymer Electrolyte Fuel Cell. J Electrochem Soc 156:B1361-B1368

[6] Yan Z, Xie J, Jing J, Zhang M, Wei W, Yin S (2012) $\mathrm{MoO}_{2}$ nanocrystals down to $5 \mathrm{~nm}$ as $\mathrm{Pt}$ electrocatalyst promoter for stable oxygen reduction reaction. Int $\mathrm{J}$ Hydrogen Energy 37:15948-15955

[7] Martins PFBD, Ticianelli EA (2015) Electrocatalytic Activity and Stability of Platinum Nanoparticles Supported on Carbon-Molybdenum Oxides for the Oxygen Reduction Reaction. Chemelectrochem 2(9):1298-1306 
[8] Micoud F, Maillard F, Bonnefont A, Job N, Chatenet M (2010) The role of the support in $\mathrm{CO}_{\mathrm{ads}}$ monolayer electrooxidation on Pt nanoparticles: $\mathrm{Pt} / \mathrm{WO}_{\mathrm{x}}$ vs. Pt/C. Phys Chem Chem Phys 12:1182-1193

[9] Pereira LGS, Paganin VA, Ticianelli EA (2009) Investigation of the CO tolerance mechanism at several Pt-based bimetallic anode electrocatalysts in a PEM fuel cell. Electrochim Acta 54:1992-1998

[10] Borbath I, Guban D, Bakos I, Paszti Z, Gajdos G, Sajo IE, Vass Á, Tompos A (2018) Exclusive formation of alloy phases via anchoring technique- From bimetallic catalysts to electrocatalysis. Catal Today 306:58-70

[11] Gubán D, Tompos A, Bakos I, Pászti Z, Gajdos G, Sajó IE, Borbáth I (2017) CO oxidation and oxygen reduction activity of bimetallic Sn-Pt electrocatalysts on carbon: effect of the microstructure and the exclusive formation of the $\mathrm{Pt}_{3} \mathrm{Sn}$ alloy. React Kinet Mech Cat 121:43-67

[12] Mukerjee S, Lee SJ, Ticianelli EA, McBreen J, Grgur BN, Markovic NM, Ross PN, Giallombardo JR, De Castro ES (1999) Investigation of enhanced CO tolerance in proton exchange membrane fuel cells by carbon supported PtMo alloy catalyst. Electrochem Solid State Lett 2(1):12-15

[13] Grgur BN, Markovic NM, Ross, PN (1999) The electro-oxidation of $\mathrm{H}_{2}$ and $\mathrm{H}_{2} / \mathrm{CO}$ mixtures on carbon-supported $\mathrm{Pt}_{\mathrm{x}} \mathrm{Mo}_{\mathrm{y}}$ alloy catalysts. J Electrochem Soc 146:1613-1619

[14] Papakonstantinou G, Paloukis F, Siokou A, Neophytides SG (2007) The electrokinetics of $\mathrm{CO}$ oxidation on $\mathrm{Pt}_{4} \mathrm{Mo}(20$ wt \%)/C interfaced with Nafion membrane. J Electrochem Soc 154(10):B989- B997

[15] Mukerjee S, Urian RC, Lee SJ, Ticianelli EA, McBreen J (2004) Electrocatalysis of CO tolerance by carbon-supported PtMo electrocatalysts in PEMFCs. J Electrochem Soc 151:A1094-A1103

[16] Papageorgopoulos DC, Keijzer M, de Bruijn FA (2002) The inclusion of Mo, Nb and Ta in Pt and PtRu carbon supported 3 electrocatalysts in the quest for improved $\mathrm{CO}$ tolerant PEMFC anodes. Electrochim Acta 48:197-204

[17] Lee SA, Park KW, Choi JH, Kwon BK, Sung YE (2002) Nanoparticle Synthesis and Electrocatalytic Activity of Pt Alloys for Direct Methanol Fuel Cells. J Electrochem Soc 149(10):A1299-A1304 
[18] Gateiger HA, Markovic NM, Ross PN, Jr. (1995) $\mathrm{H}_{2}$ and CO Electrooxidation on WellCharacterized Pt, Ru, and Pt-Ru. 1. Rotating Disk Electrode Studies of the Pure Gases Including Temperature Effects. J Phys Chem 99:8290-8301

[19] Ross PN, Jr, Kinoshita K, Scarpellino AJ, Stonehart P (1975) Electrocatalysis on binary alloys. II. Oxidation of molecular hydrogen on supported Pt $+\mathrm{Ru}$ alloys. J Electroanal Chem 63:97-110

[20] Grgur BN, Zhuang G, Markovic NM, Ross PN (1997) Electrooxidation of $\mathrm{H}_{2} / \mathrm{CO}$ mixtures on a well-characterized $\mathrm{Pt}_{75} \mathrm{Mo}_{25}$ alloy surface. J Phys Chem B 101:3910-3913

[21] Grgur BN, Markovic NM, Ross PN (1998) Electrooxidation of $\mathrm{H}_{2}, \mathrm{CO}$, and $\mathrm{H}_{2} / \mathrm{CO}$ mixtures on a well-characterized $\mathrm{Pt}_{70} \mathrm{Mo}_{30}$ bulk alloy electrode. J Phys Chem B 102:24942501

[22] Dos Anjos DM, Kokoh KB, Léger JM, De Andrade AR, Olivi P, Tremiliosi-Filho G (2006) Electrocatalytic oxidation of ethanol on Pt-Mo bimetallic electrodes in acid medium. J Appl Electrochem 36:1391-1397

[23] Igarashi H, Fujino T, Zhu Y, Uchida H, Watanabe M (2001) CO Tolerance of Pt alloy electrocatalysts for polymer electrolyte fuel cells and the detoxification mechanism. Phys Chem Chem Phys 3:306-314

[24] Takabatake Y, Noda Z, Lyth SM, Hayashi A, Sasaki K (2014) Cycle durability of metal oxide supports for PEFC electrocatalysts. Int J Hydrogen Energy 39:5074-5082

[25] Micoud F, Maillard F, Gourgaud A, Chatenet M (2009) Unique CO-tolerance of Pt-WO materials. Electrochem Commun 11:651-654

[26] Ioroi T, Akita T, Yamazaki S, Siroma Z, Fujiwara N, Yasuda K (2006) Comparative study of carbon-supported $\mathrm{Pt} / \mathrm{Mo}$-oxide and $\mathrm{PtRu}$ for use as $\mathrm{CO}$-tolerant anode catalysts. Electrochim Acta 52:491-498

[27] Ma L, Zhao X, Si F, Liu C, Liao J, Liang L, Xing W (2010) A comparative study of Pt/C and $\mathrm{Pt}-\mathrm{MoO}_{\mathrm{x}} / \mathrm{C}$ catalysts with various compositions for methanol electro-oxidation. Electrochim Acta 55:9105-9112

[28] Elezović NR, Babić BM, Radmilović VR, Gojković SLj, Krstajić NV, Vračar LjM (2008) Pt/C doped by $\mathrm{MoO}_{\mathrm{x}}$ as the electrocatalyst for oxygen reduction and methanol oxidation. J Power Sources 175:250-255 
[29] Pozio A, Giorgi L, Antolini E, Passalacqua E (2000) Electroxidation of $\mathrm{H}_{2}$ on Pt/C, Pt$\mathrm{Ru} / \mathrm{C}$ and Pt-Mo/C anodes for polymer electrolyte fuel cell. Electrochim Acta 46:555-561

[30] Maillard F, Peyrelade E, Soldo-Olivier Y, Chatenet M, Chaînet E, Faure R (2007) Is carbon-supported Pt- $\mathrm{WO}_{\mathrm{x}}$ composite a CO-tolerant material? Electrochim Acta 52:1958-1967

[31] Li R, Hao H, Huang T, Yu A, (2012) Electrodeposited Pd-MoO ${ }_{x}$ catalysts with enhanced catalytic activity for formic acid electrooxidation. Electrochim Acta 76:292-299

[32] Vellacheri R, Unni SM, Nahire S, Kharul UK, Kurungot S (2010) Pt- $\mathrm{MoO}_{\mathrm{x}}$-carbon nanotube redox couple based electrocatalyst as a potential partner with polybenzimidazole membrane for high temperature Polymer Electrolyte Membrane Fuel Cell applications. Electrochim Acta 55: 2878-2887

[33] Ordóñez LC, Roquero P, Sebastian PJ, Ramírez J (2007) CO oxidation on carbonsupported PtMo electrocatalysts: Effect of the platinum particle size. Int J Hydrogen Energy, $32: 3147-3153$

[34] Ioroi T, Yasuda K, Siroma Z, Fujiwara N, Miyazaki Y (2003) Enhanced CO-Tolerance of Carbon-Supported Platinum and Molybdenum Oxide Anode Catalyst. J Electrochem. Soc 150:A1225-A1230

[35] Martínez-Huerta MV, Rodríguez JL, Tsiouvaras N, Pena MA, Fierro JLG, Pastor E (2008) Novel synthesis method of CO-tolerant PtRu-MoO $\mathrm{M}_{\mathrm{x}}$ nanoparticles: structural characteristics and performance for methanol electrooxidation. Chem Mater 20:4249-4259

[36] Zhang H, Wang Y, Fachini ER, Cabrera CR (1999) Electrochemically Codeposited Platinum/Molybdenum Oxide Electrode for Catalytic Oxidation of Methanol in Acid Solution. Electrochem. Solid State Lett. 2(9):437-439.

[37] Çakar İ, Özdokur KV, Demir B, Yavuz E, Demirkol DO, Koçak S, Timur S, Ertaş FN (2013) Molybdenum oxide/platinum modified glassy carbon electrode: A novel electrocatalytic platform for the monitoring of electrochemical reduction of oxygen and its biosensing applications. Sensors and Actuators B: Chemical 185:331- 336.

[38] Yavuz E, Özdokur KV, Cakar I, Kocak S, Ertas FN (2015) Electrochemical Preparation, Characterization of Molybdenum-Oxide/Platinum Binary Catalysts and Its Application to Oxygen Reduction Reaction in Weakly Acidic Medium. Electrochim Acta 151:72-80

[39] Samjeske G, Wang H, Löffler T, Baltruschat H (2002) CO and methanol oxidation at Ptelectrodes modified by Mo. Electrochim Acta 47:3681-3692 
[40] Massong H, Wang H, Samjeské G, Baltruschat H (2000) The co-catalytic effect of Sn, $\mathrm{Ru}$ and Mo decorating steps of $\mathrm{Pt}(111)$ vicinal electrode surfaces on the oxidation of CO. Electrochim Acta 46:701-707

[41] Cafarova SF, Aliyev AS, Elrouby M, Soltanova N, Tagiyev DB (2015) Studying the electrochemical deposition process of molybdenum from aqueous solution of molybdate ions. J Electrochem Sci Eng 5(4):231-235

[42] Lu J, Li WS, Du JH, Fu JM (2005) Co-deposition of $\mathrm{Pt}-\mathrm{H}_{\mathrm{x}} \mathrm{MoO}_{3}$ and its catalysis on methanol oxidation in sulfuric acid solution. J New Mat Electrochem Systems 8:5-14.

[43] Shropshire JA (1965) The catalysis of the electrochemical oxidation of formaldehyde and methanol by molybdates. J Electrochem Soc 112:467-469

[44] Nakajima H, Kita H (1990) The role of surface molybdenum species in methanol oxidation on the platinum electrode. Electrochim Acta 35:849-853

[45] Horkans J, Shafer MW (1977) Effect of orientation, composition, and electronic factors in the reduction of $\mathrm{O}_{2}$ on single crystal electrodes of the conducting oxides of molybdenum and tungsten. J Electrochem Soc 124:1196-1202

[46] Zhang Z, Liu J, Gu J, Su L, Cheng L (2014) An overview of metal oxide materials as electrocatalysts and supports for polymer electrolyte fuel cells. Energy Environ Sci 7:25352558

[47] De Rosa L, Tomachuk CR, Springer J, Mitton DB, Saiello S, Bellucci F (2004) The wet corrosion of molybdenum thin film. Part I: Behavior at $25^{\circ} \mathrm{C}$. Mater Corros 55:602-609

[48] Borgschulte A, Sambalova O, Delmelle R, Jenatsch S, Hany R, Nüesch F (2017) Hydrogen reduction of molybdenum oxide at room temperature. Sci. Rep. 7, 40761; doi: 10.1038/srep40761

[49] Wang Y, Fachini ER, Cruz G, Zhu Y, Ishikawa Y, Colucci JA, Cabrera CR (2001) Effect of surface composition of electrochemically codeposited platinum/molybdenum oxide on methanol oxidation. J Electrochem Soc 148:C222-C226

[50] Saji VS, Lee CW (2012) Molybdenum, molybdenum oxides, and their electrochemistry. ChemSusChem 5(7):1146-1161

[51] Mayrhofer KJJ, Hartl K, Juhart V, Arenz M (2009) Degradation of Carbon-Supported Pt Bimetallic Nanoparticles by Surface Segregation. J Am Chem Soc 131:16348-16349 
[52] Gubán D, Borbáth I, Pászti Z, Sajó IE, Drotár E, Hegedűs M, Tompos A (2015) Preparation and characterization of novel $\mathrm{Ti}_{0.7} \mathrm{~W}_{0.3} \mathrm{O}_{2}-\mathrm{C}$ composite materials for Pt-based anode electrocatalysts with enhanced CO tolerance. Appl Catal B: Environ 174:455-470

[53] Gubán D, Tompos A, Bakos I, Vass Á, Pászti Z, Szabó EG, Sajó IE, Borbáth I (2017) Preparation of CO-tolerant anode electrocatalysts for polymer electrolyte membrane fuel cells. Int J Hydrogen Energy 42:13741-13753

[54] Vass Á, Borbáth I, Pászti Z, Bakos I, Sajó IE, Németh P, Tompos A (2017) Effect of Mo incorporation on electrocatalytic performance of Ti-Mo mixed oxide-carbon composite supported Pt electrocatalysts. React Kinet Mech Cat 121:141-160

[55] Alcaide F, Álvarez G, Tsiouvaras N, Pena MA, Fierro JLG, Martínez-Huerta MV (2011) Electrooxidation of $\mathrm{H}_{2} / \mathrm{CO}$ on carbon-supported $\mathrm{PtRu}-\mathrm{MoO}_{\mathrm{x}}$ nanoparticles for polymer electrolyte fuel cells. Int J Hydrogen Energy 36:14590-14598

[56] Fairley N (2006) "CasaXPS: Spectrum Processing Software for XPS, AES and SIMS," Version 2.3.13, Casa Software Ltd, Cheshire. http://www.casaxps.com

[57] Mohai M. "XPS MultiQuant: Multimodel XPS Quantification Software,” Surface and Interface Analysis 36(8), pp. 828-832. 2004.

[58] S. Geiger, S. Cherevko, K.J.J. Mayrhofer (2015) Dissolution of Platinum in Presence of Chloride Traces. Electrochim Acta 179:24-31

[59] B. R. Shrestha, E. Tada, A. Nishikata (2014) Effect of Chloride on Platinum Dissolution. Electrochim Acta 143:161-167

[60] Aguiar ACR, Olivi P (2010) Characterization and voltammetric behavior of $\mathrm{Pt}_{\mathrm{y}} \mathrm{Mo}_{\mathrm{z}} \mathrm{O}_{\mathrm{x}} / \mathrm{C}$ electrodes prepared by the thermal decomposition of polymeric precursors. J Power Sources 195:3485-3489

[61] Ioroi T, Fujiwara N, Siroma Z, Yasuda K, Miyazaki Y (2002) Platinum and molybdenum oxide deposited carbon electrocatalyst for oxidation of hydrogen containing carbon monoxide. Electrochem Commun 4:442-446

[62] Jaksic JM, Vracar Lj, Neophytides SG, Zafeiratos S, Papakonstantinou G, Krstajic NV, Jaksic MM (2005) Structural effects on kinetic properties for hydrogen electrode reactions and CO tolerance along Mo-Pt phase diagram. Surf Sci 598:156-173 
[63] Lebedeva NP, Janssen GJM (2005) On the preparation and stability of bimetallic PtMo/C anodes for proton-exchange membrane fuel cells. Electrochim Acta 51:29-40

[64] Wang GF, Van Hove MA, Ross PN, Baskes MI, (2005) Quantitative prediction of surface segregation in bimetallic Pt-M alloy nanoparticles (M= Ni, Re, Mo) Prog. Surf. Sci. 79:28-45

[65] Guillén-Villafuerte O, García G, Rodríguez JL, Pastor E, Guil-López R, Nieto E, Fierro JLG (2013) Preliminary studies of the electrochemical performance of $\mathrm{Pt} / \mathrm{X} @ \mathrm{MoO}_{3} / \mathrm{C}(\mathrm{X}=$ $\mathrm{Mo}_{2} \mathrm{C}, \mathrm{MoO}_{2}, \mathrm{Mo}^{0}$ ) catalysts for the anode of a DMFC: Influence of the Pt loading and Mophase. Int J Hydrogen Energy 38:7811-7821

[66] Baltrusaitis J, Mendoza-Sanchez B, Fernandez V, Veenstra R, Dukstiene N, Roberts A, Fairley N (2015) Generalized molybdenum oxide surface chemical state XPS determination via informed amorphous sample model. Appl Surf Sci 326:151-161

[67] Schroeder T, Zegenhagen J, Magg N, Immaraporn B, Freund HJ (2004) Formation of a faceted $\mathrm{MoO}_{2}$ epilayer on Mo(112) studied by XPS, UPS and STM. Surf Sci 552:85-97

[68] Scanlon DO, Watson GW, Payne DJ, Atkinson GR, Egdell RG, Law DSL (2010) Theoretical and Experimental Study of the Electronic Structures of $\mathrm{MoO}_{3}$ and $\mathrm{MoO}_{2}$. J Phys Chem C 114:4636-4645 